\title{
Stretching the Improvement of the Home Industry for UsekPaninggaran Crackers in the Islamic Economy
}

\author{
Refanza Riskiyani' ${ }^{1}$ Hendri Hermawan $\mathbf{A}^{2}$ \\ E-mail : 23refanzariskiyani@gmail.com ${ }^{1}$ \\ 1,2Institusi Agama Islam Negeri Pekalongan \\ 1,2Jl. Kusuma Bangsa No.9,Panjang Baru, Kota Pekalongan, Jawa Tengah
}

\begin{abstract}
Abstrak
Maraknya bisnis Home Industry di Kecamatan Paninggaran menunjukan bahwa geliat disektor UMKM begitu pesat. Desa Paninggaran adalah salah satu desa dengan pendapatan masyarakat diperolehdari hasil penjualan kerupuk usek. Sehingga tidak heran desa Paninggaran dikenal dengan ciri khas kerupuk usek. Kerupuk Usek dikenal dengan nama kerupuk pasir karena saat proses penggorengan menggunakan pasir yang sudah dipanaskan. Tujuan dari penelitian ini ialah untuk mengetahui secara perspektif ekonomi islam tentang pengelolaan produksi dan pemasaran hingga branding usaha rumahan kerupuk usek agar dapat meningkatkan niai perekonomian di Desa Paninggaran. Penelitian ini menggunakan jenis penelitian lapangan (field reseach) dan metode pengumpulan data menggunakan observasi, wawancara dan dokumentasi. Hasil penelitian dilapangan menunjukan pngelolaan produksi kerupuk usek di Desa Paninggaran sudah sejalan dengan syariat islam meskipun belum ada izin pelebelan atau merek yang bertanda halal . usaha ini mampu memberikan peningkatan ekonomi keluarga pengusaha kerupuk dan dapat mengurangi tingkat pengangguran terhadap masyarakat di Desa Paninggaran.
\end{abstract}

Kata Kunci: Home Industri, faktor produksi , Ekonomi Islam.

\begin{abstract}
The rise of the Home Industry business in Paninggaran District shows that the MSME sector is growing very rapidly. Paninggaran Village is one of the villages where community income is obtained from the sale of usek crackers. So it's not surprising that Paninggaran village is known for its typical usek crackers. Usek crackers are known as sand crackers because during the frying process they use heated sand. The purpose of this study is to find out from an Islamic economic perspective about production management and marketing to branding of usek crackers at home in order to increase the economic value in Paninggaran Village. This study uses a type of field research (field research) and data collection methods using observation, interviews and documentation. The results of the research in the field show that the management of usek cracker production in Paninggaran Village is in line with Islamic law, although there is no labeling permit or brand marked as halal. This business is able to provide an increase in the economy of the cracker entrepreneur family and can reduce the unemployment rate for the community in Paninggaran Village.
\end{abstract}

Keywords: Home Industry, factor of production, Islamic economics. 


\section{Introduction}

Indonesia has the largest economic growth value of one of the many countries in the world and includes developing countries in the emerging economy category (Larasasati \& Natasya, 2017: 154-155). Behind the high economic growth is the contribution of the private sector, namely micro, small and medium enterprises (MSMEs). MSME is an economic business activity owned by an individual or a business entity according to established criteria. However, the Covid 19 pandemic emerged which had a negative impact on optimizing Indonesia's economic conditions, especially in the business sector. The existence of MSMEs has become the largest part of the economy in several economic sectors during the pandemic. MSMEs have an important role in reviving the Indonesian economy with the aim of increasing the power and standard of living of the community. (Wahyunti, 2020: 281-282).

The growth of MSMEs in Indonesia for the last two years has continued to increase, but in 2019 the decline occurred until 2020 due to the Covid-19 pandemic. This pandemic has had a demanding effect on the existence of MSME entrepreneurs so that they can continue to rise and survive. The existence of MSMEs reflects the real manifestation of the social economy of Indonesian society which is characterized by local wisdom, but there are still various problems that need to be considered by all parties (Pratiwi et al., 2021: 14).

The pandemic conditions have made business actors sluggish, many business sectors have been affected, both in the service, tourism, fashion and modern and traditional food sectors. This happens because of government regulations to stay in the home environment and it is forbidden to open businesses that have the potential to invite crowds. (Fanaqi et al., 2020:263).

This situation creates social turmoil which results in unequal economic growth and will result in inefficiency in the nation's economy. According to estimates by experts, it is stated that the stretching of the business in growing the national economy is less than optimal in optimizing the economy of the wider community, especially the small community. This can happen because of increased economic growth, only dominated by conglomerate people during this pandemic (Shiddiqi \& Nikmah, 2020:15-16). 
However, the efforts made by the government towards welfare in Indonesia continue, one of which is making policies that prioritize the industrial sector and creative human resources. What is meant by industry is a process of human activity to process a raw material into something that has a sale and purchase value (Aisyah Nurul Fitriana, Irwan Noor, 2014: 281-283).

The industrial sector intended to be developed by business actors is small industry in rural areas or (home industry). Small industries in rural areas have an important role in encouraging the community to improve the economy. The benefits of the home industry include: providing the employment sector, providing additional family income, and being able to produce products for the needs of the surrounding population independently and have an economic selling value compared to large industries (Masduki et al., 2019:430).

Thus, the home industry is one of the community's efforts in survival service which is managed by the family. According to Kloter and Armstrong, of course, it is undeniable that the home industry will also design and implement marketing strategies by understanding five concepts such as: concepts that explain products, concepts of production, concepts related to sales, concepts of distribution and social marketing concepts (Emiliasari et al. al., 2020: 109).

Home industry production is crowded among rural areas to support survival. Not a few rural communities who have a sufficient economy from the results of the 



\section{Stretching the Improvement of the Home Industry for UsekPaninggaran Crackers in the Islamic Economy Refanza Riskiyani dan Hendri Hermawan A}

Home Industry business that is run. In the current era, the Home Industry business is more widely known to the public, because basically this business is widely cultivated by the community and there are some that are shaded by business entities. This can be seen from the increasing number of business units. On the other hand, of course, competition in today's industrial world is getting stronger and tighter. And the effect is to provide a spur for business actors to continue to innovate and improve their industry, both in marketing strategies, innovation strategies and branding strategies. (Riza Kurniawati Alfizain, 2020: 1)

In carrying out the marketing strategy, these home industry business actors need facilities or infrastructure for their business activities, both in the production and buying and selling processes. One of the means for home industry business actors in carrying out buying and selling is the market, namely the traditional market and modern market. The existence of this facility provides benefits for business actors in marketing their products to be widely known by the public and also provides benefits for traders and buyers which are basically mutually beneficial (Muhammad, 2013:1-2).

In addition, business actors are required to have innovations that have high selling value in their products. Innovation means an idea or idea that is not yet known and practiced by the wider community as a means of progress and public welfare. In other words, innovation can also be intended as new creativity carried out by someone (Sukmadi, 2016).

The existence of this new creativity or innovation provides a different value to a product, therefore an innovation strategy is needed. Innovation strategy is defined as a basic component to determine the course of business innovation based on strategic objectives and business strategies. This innovation or competitive strategy plays a very important role for business actors in determining competitive advantage. (Hittmár et al., 2014: 1195).

Then in the industrial world, of course, there are strategies to compete. This competitive strategy is a strategy carried out by entrepreneurs in the face of competition between entrepreneurs. This strategy is generally interpreted as a process within the industry to develop and build various strategic resources that have high capabilities in competitive advantage (Siswati \& Alfiansyah, 2020: 84).

With regard to competitive advantage, of course, trademarks are a potential 
that will support home industry products among the wider community. A trademark is a sign or a combination to distinguish goods or services from one entity to another. The signs include: words, individual names of letters, numbers, and color combinations. As an implementation, through the use of brands used in product markers from MSME entrepreneurs so that consumers can easily find and buy these products (Sardjono et al., 2013:471).

One of the functions of the brand is so that consumers can characterize a product and also to be market-oriented properly. According to Sinkula (1994) market orientation is the ability to recognize, explore and explain information about the need for goods or services desired by customers. In other words, market orientation also affects performance in developing an entrepreneurship. (Adinoto, 2013: 2) In the business world, the brand and reputation of a product have a very important role for consumers. Moreover, if the brand or brand is managed effectively and efficiently, it will have a positive impact on the readiness of MSME actors to compete with other MSMEs.

In the business world, it is a world of competition, so it is not surprising that in MSMEs there are a lot of competitive challenges. Efforts to obtain a large profit is one of the forms of competition. The basis for competition policy has the essence in Law no. 5 of 1999 and followed by the establishment of the KPPU to confirm and supervise compliance with the law. (Mantili et al., 2016:121)

According to Mansur Malaka, in the concept of Islamic economics there is a perfectly competitive market, namely a market structure that ensures the efficient and optimal production of goods or services. Then the seller and buyer know each other information related to the price of the goods or services. It is the market power that determines the price, namely the strength of supply and demand. (Malaka, 2014:48)

This market structure that focuses on controlling the market can result in unfair business competition because it makes a large increase in profits (Muda Restu Pratama, 2017:663). The level of competition in small industries requires business actors or marketers to be able to carry out their marketing activities more effectively and efficiently. And these marketing activities require a basic marketing concept in 


\section{Stretching the Improvement of the Home Industry for UsekPaninggaran Crackers in the Islamic Economy Refanza Riskiyani dan Hendri Hermawan A}

accordance with the interests of marketers and customer desires (Alma and Riyansyah, 2014: 340). So a management process is needed as an effort to optimize the level of business competition. Basically the management process is a definite plan and aims to provide benefits and confidence according to the rules (Hafidhuddin and Tanjung, 2003: 3).

At this time Pekalongan Regency has good industrial potential which is evidenced by the large number of small and medium industries. There are excellent products in Pekalongan Regency, especially in the textile sector such as batik, negligee, and jeans. Besides that, Pekalongan Regency has other superior products that are now developing in the community such as processed fruit, chips, crackers and other creative industries. The large number of small industrial business activities in Pekalongan Regency provides great opportunities for the community in increasing income and optimizing the economy, especially during the current pandemic, one of which is in Paninggaran Village.

The rise of the Home Industry business in Paninggaran District shows that the MSME sector is growing very rapidly. Paninggaran Village is one of the villages where people's income is obtained from the sale of used crackers. So it's not surprising that Paninggaran village is known for its typical usek crackers. Usek crackers are known as sand crackers because during the frying process they use heated sand. The raw material is starch or starch and is seasoned with a secret spice. There are two taste innovations such as spicy and savory flavors. The great interest of these consumers made the people of Paninggaran Village start to make this Usek traditional cracker business a necessity of life. However, product marketing is still traditional because the product is only marketed around the markets in the Paninggaran District area although there are some outside the Paninggaran District area and the product is not widely known. With this effort, it is hoped that it can increase people's income and can prosper the families in Paninggaran Village. 


\section{Literature Review}

\section{Strategic Management}

Strategic Management is an arrangement that has a function as a science and art to implement, formulate and supervise decisions within the organization in accordance with the goals to be achieved (Fred R. David, 2006: 6). In a sense, strategic management is defined as a process of activities related to a number of stages and sequentially. There are four stages of the strategic management process including: first, Environmental Analysis. Second, Strategy Formulation. Third, Strategy Implementation. Fourth, Evaluation \& Control (Usep Sudrajat and Suwaji, 2018: 4). So from these stages it can be concluded that strategic management is a collection of several decisions and an action that produces rules and implementation plans to achieve the goals of an organization or company. As implied in the definition, strategic management focuses on integrating management, marketing, finance or accounting, product, research, development, and computer information systems to achieve organizational goals. Meanwhile, according to Wheelen and Hunger strategic management is a set of managerial decisions and long-term decision-making actions within the company (Hunger, Thomas L Wheelen, 2012: 53).

According to David Strategy is a collection of activities that are different from the previous ones to provide added value to clients so that they can achieve the medium-term or long-term goals of the company. According to a typical business, the company will consider three strategic models, namely: functional strategy, corporate strategy and business strategy (David, 2006:252). Meanwhile, according to David, the types of strategies are as follows: a. Integration Strategy 1) Forward integration. Forward integration is an effort to have or increase control over distributors or retailers. 2) Backward integration. Backward integration is a strategy to try to have or increase control over a supplier company. 3) Horizontal Integration (Horizontal Integration). The horizontal integration growth strategy is carried out through the acquisition of competing companies that have the same line of business.

\section{SWOT analysis}

SWOT analysis is the identification of various factors systematically to formulate corporate strategy. 10 This analysis is based on logic that can maximize 


\section{Stretching the Improvement of the Home Industry for UsekPaninggaran Crackers in the Islamic Economy Refanza Riskiyani dan Hendri Hermawan A}

strengths and opportunities, but simultaneously minimize weaknesses and threats. According to David, all organizations have strengths and weaknesses in the functional areas of business.11 No company is equally strong or weak in all areas of business. Internal strengths or weaknesses combined with external opportunities or threats and a clear mission statement, form the basis for setting goals and strategies. Goals and strategies are set with the intention of exploiting internal strengths and overcoming weaknesses. The elements of a SWOT analysis is a method used to evaluate the strengths, weaknesses, opportunities and threats in a business. Generally SWOT is described by a table on a large paper size to facilitate the analysis of the relationship between its aspects. Making a SWOT analysis involves specific business goals and identification of internal-external factors to achieve these goals. The following are the elements of a SWOT analysis, namely: a. Strengths are resources, skills, or other advantages related to the company's competitors and market needs that the company is expected to serve. Strength is a special competition that gives a company a competitive advantage in the market place. b. Weaknesses are limitations or deficiencies in resources, skills, and capabilities that effectively hinder the company's performance. These limitations can be in the form of facilities, financial resources, management capabilities, and marketing skills which can be a source of company weaknesses. c. Opportunities are important situations that are profitable in the corporate environment. Important trends are one source of opportunities, such as technological changes and increasing relationships between companies and buyers or suppliers are a picture of opportunities for companies d. Threats are important unfavorable situations in the corporate environment. Threats are a major nuisance to the company's current or desired position. The existence of new or revised government regulations can be a threat to the company's success (Rangkuti, 2006).

Broadly speaking, there are two main factors that influence the SWOT analysis, namely internal factors and external factors. To better understand these two factors, the following is the explanation according to Fred R. David: a. Internal factors are factors that come from within a company, namely the strengths and weaknesses of the company itself. As for some things that are part of the internal factors are: ) Competent human resources 2) Property of the latest technology 3) Public trust in the company 4) Good marketing ability 5) Good distribution ability. b. 
External factors are all factors that come from outside the company (threats and opportunities) and affect the company's performance. As for some things that are part of the external factors are: 1) Business trends 2) Community culture 3) Social politics and ideology 4) Economic conditions of a country 5) Government regulations and policies 6) Technological developments.

\section{Business development}

Business is a process of activity to achieve a certain profit. In general, entrepreneur means a person who is able to take risks and is independent. Entrepreneurial activities themselves can be carried out by individuals or groups with the aim of making a profit. (Kasmir, 2011:19) Language development means improving quality and fostering (Siti Komariah, 2020:30). There are four concepts of business empowerment which can be briefly stated as follows: a. People's economy b. Business empowerment c. Structural changes (Sumidingrat Gunawan, 2002:36). The steps that must be taken are by providing training as a very important provision when they enter the world of entrepreneurship, the sustainable development program is carried out through several stages of activities, namely: a. Business training b. Apprenticeship c. Preparation of proposals d. Capital capital in the form of money e. Mentoring f. Business network (Fitri Agustina Mayasari, 2006:12).

In carrying out a business, must have a desire to achieve success. The following are the main factors that cause an industry/industry to develop well if it is owned. a. Main factors, in the form of capital, labor, raw materials or raw materials, transportation, energy sources, and marketing. b. Supporting factors, in the form of community culture, technology, government, community support, natural conditions, and economic conditions. Based on Jevlec's opinion, the following are some of the capitals in economic development: a. Improved Access This program is aimed at reducing the limitations of public access, which includes access to funding, market information and community business development. b. Capacity building This program is aimed at increasing the capacity of both individuals and organizations in the context of developing community economic enterprises. Several programs that will be carried out within the scope of the focus of this program are: 1) Facilities for improving human resources, $\mathrm{CBO}$ and $\mathrm{BSO}$ institutions in managing and improving community economic business performance. 2) Capacity building facilities in 
technology and skills entrepreneurs. c. Increasing community business productivity This program is aimed at increasing the productivity of the community's economic business as well as expanding the scale of its business. Several programs that will be carried out within the scope of the focus of this program are: 1) Micro business development facilities 2) Facilities for various efforts to increase the productivity of the community's economic business (Saparudin, 2018).

\section{Production}

Production is an economic activity in supporting consumption activities. The existence of production activities provides benefits for consumers because if there is no production there will be inequality in the economic sector. In this case, there is a symbiotic mutualism where producers and consumers are interrelated (M. Nur Rianto Al Arif, 2010: 147). In the Islamic economic system, production is one of the most important things. From the concept and idea of production, it is emphasized that the main goal to be achieved by economic activity theorized by the Islamic economic system is for the benefit of the individual, the benefit in a balanced way (Mawardi, 2007:65). According to Chapra, the purpose of production is to fulfill the basic needs of each individual and to ensure that everyone has a standard of living that is humane, honorable and in accordance with human dignity as caliph. Not meeting these needs can cause basic problems for humans. Therefore, every Muslim must also try to increase his income so that he becomes a mustahiq who can help the weak through the payment of zakat, infaq, alms and waqf. The production objectives according to Monzer Kahf include: a. Man's efforts to improve not only his material condition. But also the moral to then be a means to achieve his goals later in the hereafter. So that products that keep people away from their moral values will be prohibited in Islam. b. The social aspect of production, namely the distribution of profits from production itself among the majority of people in the fairest way. This is the main goal of the community's economy. The Islamic economic system is more related to the welfare of society than any other system. c. Economic problems are not problems that are rarely related to the necessities of life, but these problems arise because of human laziness and negligence in their efforts to take the maximum benefit from God's grace.

The following factors of production, namely: a. Manpower Manpower is human capital for a company. In various types of production, manpower is an asset 
for the success of a company. The success of a production lies in the performance of the human resources in it, including the performance of the workforce. In the Qur'an, it calls on every Muslim to invest energy, mind, and time in doing righteous deeds, deeds that are productive and very detrimental to those who waste time, who are lazy and idle, and people who work but do not produce benefits. (Ika Yunia Fauzia, 2014: 119). b. Capital Capital is a very important factor in a production. Without capital, producers will not be able to produce a good or service. In Islam, the capital of a business must be free from usury. Several ways to obtain capital, Islam regulates a good system, by means of mudharabah or musyarakah cooperation. This is to maintain the rights of the owners of capital in order to achieve a good in a production activity which will ultimately have implications for the existence of a problem in a collaboration carried out by each party (Ika Yunia Fauzia, 2014). c. Raw Materials When a producer is going to produce a good/service, one of the things that must be considered is the raw material. Because if the raw materials are available properly, then the production will run smoothly. Otherwise it will hinder the course of a production. d. Management Management is the art of getting work done through other people, Mary P.Follet's definition means that a manager is in charge of organizing and directing other people to achieve organizational goals. management in small industries there are several things that need to be considered, namely: 1) Capital Management is the process of how to manage capital for the company's operational costs. 2) Inventory Management is a number of materials which include raw materials, auxiliary materials and finished goods that have not been sent to customers. The availability of inventory determines the continuity of the production process. Delays in inventory will also disrupt the production process, and if not addressed immediately will affect the company's marketing. The amount of inventory that is too large is not always profitable, it can even be very detrimental. 3) Production management still applies the control or control function. The mechanism for implementing the control function can be carried out during the production process or when the product is finished. In production management, the control implementation stage can be carried out by inspection, inspection is an activity carried out in the form of examining every part of the finished goods and the inspector has the right to determine whether the goods are good or bad (Barrett, 
2003: 51). 4) Marketing Management Marketing management discusses all efforts to move goods and services from producers to consumers or end users. In marketing there are several stages that must be considered, including choosing a pricing objective, determining demand and estimating costs (K. Kotler, 2007: 84).

\section{Home Industri}

Home Business or Home Industry is a place that is used as a business facility for both service and trade businesses. At first this home-based business had the concept of entrepreneurs and professionals, but now it is starting to spread widely among the general public. In reviewing the strategic location of this home-based business, the development of entrepreneurial principles has an important role in opening up a forward-thinking mindset to people who have home-based businesses. Home Industry is used by the community as a means to earn income (Alkim, 2005:3). There are several roles of Home industry in improving the community's economy, including:

1) Can strengthen the national economy with various business linkages and function as a transformer between fields.

2) Small businesses are used to increase efficiency and effectiveness in the economic sector and in particular can take advantage of existing resources.

3) Small businesses are seen by the community as a means of exchanging national profits, a tool for economic stability, the reason being that there are many small businesses that are scattered in both urban and rural areas (Suryana, 2006: 77).

c. Raw Materials When a producer is going to produce a good/service, one of the things that must be considered is the raw material. Because if the raw materials are available properly, then the production will run smoothly. Otherwise it will hinder the course of a production. d. Management Management is the art of getting work done through other people, Mary P.Follet's definition means that a manager is in charge of organizing and directing other people to achieve organizational goals. management in small industries there are several things that need to be considered, namely: 1) Capital Management is the process of how to manage capital for the company's operational costs. 2) Inventory Management is a number of materials which include raw materials, auxiliary materials and finished goods that have not been sent to customers. The availability of inventory determines the continuity of the 
production process. Delays in inventory will also disrupt the production process, and if not addressed immediately will affect the company's marketing. The amount of inventory that is too large is not always profitable, it can even be very detrimental. 3) Production management still applies to the control or control function. The mechanism for implementing the control function can be carried out during the production process or when the product is finished. In production management, the control implementation stage can be carried out by inspection, inspection is an activity carried out in the form of examining every part of the finished goods and the inspector has the right to determine whether the goods are good or bad (Barrett, 2003: 51). 4) Marketing Management Marketing management discusses all efforts to move goods and services from producers to consumers or end users. In marketing there are several stages that must be considered, including choosing a pricing objective, determining demand and estimating costs (K. Kotler, 2007: 84).

\section{Branding}

Branding is a linguistic understanding, namely: giving symbols, names, identities. And in terms, branding serves to identify the name or type of product owned by a company, besides that branding also acts as a differentiator between other people's goods or services (Kotler, 2009). The brand also has a percentage that is more than just a product symbol because the brand is a sign that states the value of the product from the factory, while the product itself is something that is purchased by consumers in the form of goods or services (Masruroh, 2018:1). Branding has a very important role, especially for consumers. According to Keller, the benefits of branding include: 1) identification of a product source; 2) assignment of responsibility to certain companies or marketers; 3) quality markers; 4) and tools for projecting product image; 5) special commitments with manufacturers; 6) determinants of external and internal search costs; 7) minimize a risk (Tjiptono, 2005).

Kotler defines a brand as a name, term, sign, symbol, or design, or a combination of these, also intended to identify the goods or services of one seller or group of sellers and to differentiate them from those of competitors. company. Because the brand is the determinant of customer purchases. So it can be said that any marketing strategy carried out by the company is actually part of the effort to 
build the brand itself. A brand can also be interpreted as a sign worn by entrepreneurs (factories, producers, and so on) on the goods produced as an identification to declare names and so on (Culture, 1996:656).

Rangkuti himself also stated that a brand is a seller's promise to consistently provide certain features, benefits and services to buyers. According to Rangkuti, the brand has six levels of understanding as follows: a. Attributes Every brand has attributes, these attributes need to be managed and created so that customers can know for sure what attributes are contained in a brand. b. Benefits In addition to attributes, brands also have a series of benefits. Consumers don't buy attributes, they buy benefits. Manufacturers must be able to translate attributes into functional benefits as well as emotional benefits. c. Brand Value also says something about value to the manufacturer. A brand that has a high value will be appreciated by consumers as a classy brand, so that it can reflect who the users of the brand are. d. Brand culture also reflects a certain culture, a product in its promotion always provides its own characteristics, thus allowing consumers to be able to produce the same results as stated in each advertisement. e. Personality This brand also reflects a certain personality. Often certain products use age-level personalities to boost or support their product brands. For example, new packaging, attractive advertising. f. Brand Users also indicate the type of consumers who use the brand. That is why marketers always use the analogy of famous people for the use of their brands (Freddy Rangkuti, 2004: 2).

Some of these definitions, it can be seen that a brand is a name or symbol that identifies a product that distinguishes it from other products so that it is easily recognized by consumers when they want to buy a product. The existence of a brand is very important for a product or service. It is not even surprising that brands are often used as criteria in evaluating a product. The definition of image in the Big Indonesian Dictionary states that image is a picture that many people have about a person, company, organization or product (W. M. Pride and Ferrell, 1989:156). With regard to brand image (brand image), Shimp argues that brand image (brand image) can be considered as a type of association that arises in the minds of consumers when remembering a particular brand. The association can simply appear in the form of certain thoughts or images that are associated with a brand, as well as when we think about other people (Shimp, 2003:12). 

Brand Image is the perception of the brand which is a reflection of consumers' memory of their association with the brand. It can also be said that brand image is a concept created by consumers for subjective reasons and personal emotions. Therefore, in this concept, consumer perception becomes more important than the actual situation. The characteristics of a brand image have three components, namely: a. Brand Association It is the act of consumers to make associations based on their knowledge of the brand, both factual knowledge and those that are sourced from experience and emotions. b. Brand value is the action of consumers in choosing a brand. Often these consumer actions are more because their perceptions of brand characteristics are linked to the values they believe in. c. Brand Positioning Is a consumer's perception of the quality of the brand which will be used by consumers in evaluating alternative brands to be selected (Ferrinadewi, 2008:156-166).

The explanation above can be concluded that brand association, brand value and brand positioning are characteristics of brand image (brand image) where the three characteristics can reflect that brand image has a relationship with consumer interest in buying an object. Factors Affecting Brand Image (Brand Image) Brand image is the second dimension of consumer-based brand knowledge (consumerbased brand knowledge) is the image of a brand. Brand image can be considered as a type of association that arises in the minds of consumers when remembering a particular brand. The association can simply appear in the form of certain thoughts or images that are associated with a brand, just as we think about other people. For example, thoughts or images about a certain friend are associated with physical characteristics, traits, even their advantages and disadvantages. Likewise, brands are associated with certain associations that are conceptualized based on type, support, strength, and uniqueness (Shimp, 2003:12).

Label is a number of information on product packaging. In general, the label must at least contain the name or brand of the product, raw materials, additional ingredients in the composition, nutritional information, expiration date, product contents, and legality information (Anton Apriyantono, 2003:68-69). Basu Swastha defines label as part of an item in the form of information (words) about the item or its sale (Basu Swastha, 2007:141). 
There are a number of information that can be used to determine whether the purchased product contains elements that are prohibited or harmful to health are as follows: 2003:27). 2. Composition and Nutritional Value In general, the nutritional information provided is water content, protein content, fat content, vitamins and minerals. What consumers need to pay close attention to is bombastic or excessive advertisements regarding the benefits and efficacy of the product, even though the actual conditions are not as advertised. 3. Expiration Limit A product must be equipped with an expiration date stating the age of use and the feasibility of using or using the product. According to PP No. 69 of 1999 concerning Food Labels and Advertisements Article 27 Paragraph 2 reads: "It is good to use before the date according to the type and durability of the product in question". Whereas Paragraph 3 reads "In the case of food products that have an expiration date of more than three months, it is permissible to only include the month and year of expiration" (Ahmadi Miru, 2007:77-79). 4. Legality Statement Legality statement provides information that the product has been registered with the Food and Drug Administration (Badan POM), in the form of a registration number code. The MD and SP codes are for local food and ML for imported food. However, there are still many products that are labeled halal, but are not registered as halal-certified products, this is especially the product with the SP code or no code at all. For such products, it is consumer knowledge that determines whether halal is in doubt or not, if in doubt, the best attitude is not to buy products with doubtful halalness (Anton Apriyantono, 2003:71).

To meet critical consumer demands, manufacturers provide labels that they have obtained from the competent authority on the packaging of the products they issue. The label is used as a guarantee that their product is fit for consumption. Food label is any information regarding food in the form of pictures, writings, a combination of both, or other forms attached to food, inserted into, affixed to, or is part of food packaging" (Law of the Republic of Indonesia No. 7 of 1996).

Labeling is closely related to marketing. The label is part of a product that conveys information about the product and sales. Broadly speaking, there are three kinds of labels, namely: 1. Brand Label, namely the brand name given to the product or stated on the packaging. 2. Descriptive Label, which is a label that provides objective information regarding the use, construction/manufacture, care/care and 
performance of the product, as well as other characteristics related to the product. 3 . Grade Label, which is a label that identifies the assessment of product quality with a letter, number, or word (Fandy Tjiptono, 2008:17).

Henri Sinamora also divides labels into 4 types specifically as follows: 1. Product label is part of the packaging of a product that contains information about the product or product sales. 2. Brand label is the brand name that is placed on the product packaging. 3. The grade label identifies the quality of the product, this label can consist of letters, numbers or other methods to indicate the quality level of the product itself. 4. Descriptive labels list the contents, describe usage and list other product characteristics. Labeling is a very important product element that deserves careful attention with the aim of attracting consumers (Henry Sinamora, 2000: 502).

\section{Sharia Economics}

Islamic economics is a system of knowledge that focuses on economic problems. Just like other conventional economic concepts. Only in this economic system, Islamic values become the foundation and basis in every activity. Some experts define Islamic economics as a science that studies human behavior in an effort to meet needs with limited means of meeting needs within the framework of sharia. However, this definition contains a weakness because it produces incompatible and non-universal concepts. Because from this definition it encourages a person to be trapped in a priori judgment (a priori judgment) whether right or wrong must still be accepted (P3EI), 2011: 14).

According to Muhammad Abdul Manan that Islamic economics is a social science which studies the economics problems of a people imbued with the values of Islam (Manan, 1980:3). So, according to Abdul Manan Islamic economics is a social science that studies the economic problems of society inspired by Islamic values. According to Syed Nawab Haider Naqvi, Islamic economics, in short, is a study of the economic behavior of representative Muslims in modern Muslim society (Naqvi, 2009: 28).

Shari'ah Economics is a science that studies actual and empirical human activity or behavior, both in production, distribution, and consumption based on Islamic Shari'ah sourced from the Qur'an and As-Sunnah and Ijma" of the scholars with the aim of achieve happiness in the world and the hereafter (Mannan, 2006: 
29). In Islamic economics, of course, it has several characteristics, not much is stated in the Koran and many basic principles, because the basics are very precise, the Koran and the sunnah discuss a lot about how Muslims should behave as consumers, producers and owners of capital, but only a few economic systems. Islamic economics emphasizes 4 characteristics, among others: a. Unity b. Balance (equilibrium) c. Freedom (free will) d. Responsibility (responsibility) (Hafidhuddin, 2003: 29).

A science certainly has a legal basis so that it can be stated as a part of the concept of knowledge. Likewise, the application of sharia in the economic field is aimed at transforming a society with an Islamic culture. Economic activities often carry out various forms of agreements. The agreement is a binder between individuals that gives birth to rights and obligations. To regulate the relationship between individuals that contains elements of fulfilling rights and obligations in the long term, in sharia principles it is required to be made in writing which is called a contract. economics in Islam. There are several laws that form the basis of thought and determination of economic concepts in Islam. Some of the basics of Islamic law include the following: a. Al-Qur'an The Qur'an provides legal provisions for muamalat, most of which are in the form of general rules; except that it's a small amount. b. Hadith Hadith provides more detailed muamalat legal provisions than the Qur'an, the hadith of the Prophet SAW narrated by Ibn Majah, Ad-Daruquthni, and others. In carrying out economic activities, the Qur'an prohibits Muslims from using vanity methods such as carrying out usury activities, committing fraud, playing with measurements and scales, gambling, taking bribes, and other vanity methods. Islamic economics has the following objectives: a. Provide harmony for life in the world. b. The value of Islam is not only for the life of Muslims but for all living creatures on earth. c. The essence of the Islamic economic process is the fulfillment of human needs based on Islamic values in order to achieve religious goals (falah).

\section{Methods}

The research method is a procedure commonly used by researchers in examining an object. The procedure is referred to as a guide for a researcher in collecting research data so that it can be effectively and efficiently in achieving the 
objectives in accordance with the research. In research design usually requires the influence of a variable in accordance with the specified problem formulation (Arikunto, 1998:3).

Types of field research (field research). Field research is to study carefully the background of the current situation, and social infections (Akbar, 2004). In this study, the type of qualitative research is used, namely this study only describes the state of the object of research, not to draw a general conclusion (Maezuki, 1983). In this study, the author collects data in the field with the theme of the author's research, namely the improvement of the usek cracker home industry in the Islamic economy. Meanwhile, the informants consisted of business actors usingk crackers in Paninggaran Village.

The data collection method consists of the first method of in-depth interviews by way of question and answer while face to face between the interviewer and the respondent. The second method is Documentation, which is document tracking carried out to obtain data in the form of journals, books and online media as supporting data related to the research focus. This tracking is done by the author to find concrete data. The third method is Observation with participation, because researchers observe directly and focus on all activities that exist in the traditional usek cracker home industry in Paninggaran Village. And the population in this study is the entire usek cracker entrepreneur in the community of Paninggaran Village, Paninggaran District, Pekalongan Regency. As for how to obtain data by drawing individuals as samples, namely in each hamlet by using the Purposive Random Sampling technique, namely from usek crackers entrepreneurs in the Paninggaran Village community, Paninggaran District, Pekalongan Regency.

Data analysis in this research is qualitatively inductive in nature, using a method of thinking that draws conclusions from a general principle which will then be applied to something specific. By using inductive thinking, the researcher wants to see the achievements of the development of the traditional usek cracker home industry to improve the economy in Paninggaran Village, Paninggaran District, Pekalongan Regency. 


\section{Discussion}

In this discussion, several discussions will be presented that are in accordance with the results of the study, so that in the description of this discussion the researcher will adjust the results of the research with the theories that have been presented. These data were obtained by researchers from observations, observations, in-depth interviews in accordance with qualitative analysis. Then after knowing how to improve the economy of the business community with the development of home industries, the findings are obtained with the theories that have been put forward by the author with the following points:

\section{The Efforts of the Usek Cracker Home Industry in Improving the Economy of Business Actors in Paninggaran Village}

Paninggaran usek crackers are one of the typical foods from Paninggaran Village, Paninggaran District which are not only an attraction for the Paninggaran community but also for people outside Paninggaran. The usek cracker home industry is included in the individual industry but its contribution to the overall national production is not large because most businesses are carried out on a small scale, namely with not so large capital, production and sales results as well.

The number of usek cracker home industries in Paninggaran Village is as many as 34 home industries. In general, this business uses the principle of kinship but has used the workforce of the community around the business. The following, according to the head of the cracker industry group used for Paninggaran village, related to the names of business actors and their production capacity, namely: Musayaroh (45 kg/production), Mustakoroh (45 kg/production), Maliah (45 $\mathrm{kg}$ /production), Niswatin (45 kg/production), Hikmah (72 kg/ production), Jumilah (23 kg/ production), Umaroh (24 kg/ production), Mrs. Fatonah (20 kg/ production), Hikmah (22 kg/ production).

In improving the Home usek cracker industry, the researcher describes several efforts made by the usek cracker business actors in Paninggaran Village, including:

a. Looking for high quality raw materials

Raw materials are the most important thing for business actors, this cracker home industry uses the main ingredient in the form of starch derived from cassava. The goal is to choose good quality cassava in order to get good and quality juice or flour which will later be used as the main ingredient for 
making sand-fried crackers. This is what business actors usek in Paninggaran Village do, one of which is done by Mrs. Hikmah.

b. Increase production

In the production of usek crackers, previously usek business actors only spent about $10 \mathrm{~kg}$ per day and now usek crackers can produce up to 1 quintal or even more per week. According to Mrs. Hikmah herself, at certain times, such as Eid and holidays, business actors usually run out of raw materials and are overwhelmed by receiving orders from their customers.

c. Expand distribution area

The cracker business used by business actors such as Mrs. Hikmah was initially only famous in Paninggaran Village, but now the efforts of business actors such as Mrs. Hikmah to expand its distribution to urban areas. The distribution of crackers used for business actors such as Mrs. Hikmah has reached Jakarta and the main thing is in tourist areas.

\section{Production Factors in increasing the usek cracker home industry in Paninggaran Village}

Based on the production mechanism of usek crackers, the production factors used to produce usedk crackers are ready to be distributed to consumers. The factors of production in the home industry business of this usek cracker include:

a. Soil is a natural resource which includes everything on earth and is a source of economics. This factor is applied properly, such as the use of vacant land used for production and drying area for crackers used. In addition, there are other uses of power such as water, sand, and light to support the production process. However, there are usek crackers business actors who dry usek crackers on the side of the road or on the roof of residents' houses, but the local community does not feel disturbed by this.

b. The capital factor, usually the capital used by home industry business actors, is purely from personal capital, there are no loans from any bank or the like. In addition, this home industry has capital in the form of a place of production, production tools and materials as well as business skills capital in producing usedk crackers. 
c. Labor factor is a factor that increases the usek cracker production process. Of the 20 usek cracker industries in Paninggaran Village, there is one that does not use labor but uses family labor. The average of these usek crackers business actors said that if they use labor with 3-4 hours of work each and the wages given each worker finishes carrying out their work, the amount of wages is Rp. 25,000-Rp. 50,000 in accordance with the agreement between the business actor and the laborer. This is in accordance with Islamic provisions where employers have given workers wages and agreed between the two.

d. The raw material factor, the main raw material is starch from cassava which is usually obtained from the starch boss at Paninggaran Market and bought directly at Wiradesa Market. In payment for this starch material, it is paid after the usek crackers are sold out and with the system delivered to the home of the business actor at the same price for the starch material. In addition, there are dyes with the R\&W brand which are already labeled halal and safe for food production and there are seasonings as flavor innovations, namely coriander, salt, garlic.

\section{Home usek cracker industry in Islamic Economy}

The production process is carried out simply using traditional tools, starting from processing cracker dough ingredients, drying crackers, cutting crackers and then frying crackers with special sand that has been cleaned to the usek cracker packaging process.

Home The usek cracker industry in Paninggaran Village, Paninggaran District, Pekalongan Regency does not yet have a halal label permit. However, this home industry is in the process in accordance with Islamic law. This can be seen from the factors of production where none of them contain elements that intersect with Islamic Economics.

In this usek cracker home industry, in terms of sales, there are no elements that are prohibited in the principle of buying and selling in Islam, for example usury, even in other aspects this business is in accordance with Islamic Economics, namely with the aim of Economic Welfare. And this home industry is able to provide an increase in the family economy of usedk cracker business actors seen from the fulfillment of primary needs for business actors and can even send their children to school and finance their families. 


\section{Conclusion}

The results of the study show that the improvement of the usek cracker home industry in Paninggaran Village is an effort made by this usek cracker home industry by looking for high-quality raw materials so that the product that will be produced will be maintained in quality, increase production so that later there will be no product running out when many consumers are asking, Expanding the distribution area is expanded to the city area and outside the Paninggaran area.

However, there are several factors in the production, including the land factor of the usek cracker business actors utilizing vacant land for the production process, the labor factor, namely the presence of labor needed to support the speed of the production process, the capital factor using personal capital which is of course free of bank interest and raw material factors. obtained from the raw material supplier itself with the same payment even though it was paid when the used crackers were sold out. Of course, in increasing this business, it is in line with Islamic Economics, namely the principle of economic welfare. And this usek cracker home industry is able to provide additional income for the business community in Paninggaran Village.

\section{References}

(P3EI), P. P. dan P. E. I. (2011). Ekonomi Islam. PT Raja Grafindo Persada.1996, U. R. I. N. 7 T. (n.d.). Undang-undang Republik Indonesia.

Adinoto, A. (2013). Pengaruh Orientasi Pasar dan Perilaku Kewirausahaan Terhadap Kepekaan Perusahaan Dan Implikasinya Pada Kinerja Perusahaan: Studi pada Penyalur Sepeda Motor di Indonesia. ULTIMA Management, 2(1), 1-25. https://doi.org/10.31937/manajemen.v2i1.166

Ahmadi Miru. (2007). Hukum Perlindungan Konsumen. PT. Rajagrafindo Persada.

Aisyah Nurul Fitriana, Irwan Noor, A. H. (2014). Pengembangan Industri Kreatif Di Kota Batu (Studi Tentang Industri Kreatif Sektor Kerajinan Di Kota Batu). Jurnal Administrasi Publik Mahasiswa Universitas Brawijaya, 2(2), 281286.

Akbar, H. U. (2004). Metodologi Penelitian Sosial. Bumi Aksara.

Alkim. (2005). Pemberdayaan Home Industri Terhadap Masyarakat Pesisir. Gramedia. 
Anton Apriyantono, N. (2003). Panduan Belanja dan Konsumsi Halal. Khairul Bayan.

Arikunto, S. (1998). Prosedur Penelitian: Suatu Pendekatan Praktek. Rineka Cipta. Barret, R. (2003). Vocation Bussiness: Training, Developing, and Motivating People, Bussiness Economics.

Basu Swastha. (2007). Azas-Azas Marketing. Liberty Yogyakarta. David, F. R. (2006). Manajemen Strategis (10th ed.). Salemba Empat.

Emiliasari, R. N., Kosmajadi, E., Inggris, P. B., Majalengka, U., Barat, J., Islam, M. P., Majalengka, P. U., \& Barat, J. (2020). Pendampingan Penerapan Manajemen Pemasaran. Jurnal PARAHITA ABDIMAS Jurnal Pengabdian Masyarakat, 1(2), 106-115.

Fanaqi, C., Pratiwi, R. M., \& Firmansyah, F. (2020). Strategi Branding Pelaku Usaha Pariwisata di Masa Pandemi. Business Innovation and Entrepreneurship Journal, 2(4), 263-273. https://doi.org/10.35899/biej.v2i4.172

Fandy Tjiptono. (2008). Strategi Pemasaran. Penerbit Andi.

Ferrinadewi, E. (2008). Merek \& Psikologi Konsumen. Implikasi pada Strategi Pemasaran. Graha Ilmu.

Fitri Agustina Mayasari. (2006). Panduan Belajar Mandiri Kewirausahaan. CVArya Duta.

Freddy Rangkuti. (2004). The Power of Brands : Teknik Mengelola Brand Equity dan Strategi Pengembangan Merek Plus Analisis Kasus dengan SPSS. Gramedia Pustaka Utama.

Hafidhuddin, D. (2003). Islam Aplikatif. Gema Insani.

Haji, B. P. S. dan P. P. H. D. J. B. M. I. dan P. (2003). Tanya Jawab SeputarProduksi Halal. Departemen Agama.

Henry Sinamora. (2000). Manajemen Pemasaran Internasional (1st ed.). Salemba Empat.

Hittmár, Š., Varmus, M., \& Lendel, V. (2014). Proposal of Model for Effective Implementation of Innovation Strategy to Business. Procedia - Social and Behavioral Sciences, 109, 1194-1198. https://doi.org/10.1016/j.sbspro.2013.12.611

Hunger, Thomas L Wheelen, J. D. (2012). Manajemen Strategis. Andi. 
Ika Yunia Fauzia, A. K. R. (2014). Prinsip Dasar Ekonomi Islam dalam Prespektif Maqashid al-Shariah. Kencana Prenada Media.

Kebudayaan, D. P. \&. (1996). Kamus Besar Bahasa Indonesia. Balai Pustaka.Kotler, K. (2007). Manajemen Pemasaran. Indeks.

Kotler, K. L. (2009). Manajemen Pemasaran (B. Sabran (ed.); 13th ed.). Airlangg.

Larasasati, C., \& Natasya, E. D. (2017). Peran Indonesia di G-20: Peluang dan Tantangan. Jurnal Hubungan Internasional, 2(2), 147-159. https://www.ejournal.unair.ac.id/JHI/article/viewFile/7302/4417

M. Nur Rianto Al Arif, E. A. (2010). Teori Ekonomi Suatu Perbadingan Ekonomi Islam dan Ekonomi Konvensional. Kencana.

Maezuki. (1983). Metodologi Riset. Bagian Penerbit Fakultas Ekonomi UII.Malaka,

M. (2014). Praktek monopili dan persaingan usaha. 7(c), 1-43.

Manan, M. A. (1980). Islamic Economics, Theory and Practice. Idarah Adabiyah.

Mannan, A. (2006). Hukum Ekonomi Syari’ah Dalam Perspektif Kewenangan Peradilan Agama. Kencana Prenada Media Group.

Mantili, R., Kusmayanti, H., \& Afriana, A. (2016). Problematika Penegakan Hukum Persaingan Usaha di Indonesia dalam Rangka Menciptakan Kepastian Hukum. PADJADJARAN Jurnal Ilmu Hukum (Journal of Law), 3(1), 116-132. https://doi.org/10.22304/pjih.v3n1.a7

Masduki, M., Hartono, T., Sardila, V., \& Arung Triantoro, D. (2019). Pemberdayaan Muslim Muallaf Melalui Home Industry Kerupuk Ikan Lomek di Desa Selat Akar. Jurnal Pemberdayaan Masyarakat: Media Pemikiran Dan Dakwah Pembangunan, 3(2), 425-450. https://doi.org/10.14421/jpm.2019.032-09

Masruroh. (2018). Analisis Branding Dalam Upaya Pengembangan Destinasi Wisata Religi Sunan Drajat.

Mawardi. (2007). Ekonomi Islam. Alfa Riau Graha Uni Press.

Muda Restu Pratama. (2017). Analisis Structure-Conduct-Performance (Scp) Pada Industri Kecil Dan Menengah Makanan Olahan KotaAnalisis Structure-ConductPerformance (Scp) Pada Industri Kecil Dan Menengah Makanan Olahan Kota Pekan (Studi Kasus Pada IKM Tahu di Kecamatan Payung Sekaki). JOMFekom, 4(1), 661-675. https://media.neliti.com/media/publications/125589-IDanalisis-dampak-pemekaran-daerah-ditinja.pdf 
Muhammad, M. M. (2013). Jurusan ilmu ekonomi fakultas ekonomi dan bisnisislam universitas islam negeri alauddin makassar 2013.

Naqvi, S. N. H. (2009). Menggagas Ilmu Ekonomi Islam, terj. M. Saiful Anam dan Muhammad Ufuqul Mubin. Pustaka Pelajar.

Pratiwi, E. T., Suriadi, S., \& Jasiyah, R. (2021). Peningkatan Sumber Daya Manusia, Digital Marketing, Dan Pengelolaan Kas Pelaku UMKM saat Pandemi Covid-19. The 2 Seminar Nasional ADPI Mengabdi Untuk Negeri Pengabdian Masyarakat Di Era New Normal Prosiding ISSN: 2746-1246, 2(2), 13-18. https://prosiding.adpi-indonesia.id/index.php/proceedings/article/view/75

Rangkuti, F. (2006). Analisis SWOT Teknik Membedah Kasus Bisnis. Gramedia Pustaka Utama.

Saparudin. (2018). Usaha kecil Mandiri.

Sardjono, A., Prastyo, B. A., \& Larasati, D. G. (2013). Pelaksanaan Perlindungan Hukum Merek Untuk Pengusaha UKM batik diPekalongan, solo, dan yogyakarta Agus Sardjono, Brian Amy Prastyo, dan Desrezka Gunti Larasati 1. Hukum Dan Pembangunan, 4, 21.

Shiddiqi, H. A., \& Nikmah, R. (2020). Pemberdayaan Kaum Perempuan Melalui Pelatihan Olahan Kripik Danong (Daun Nongko) Dan Stick Tempe Di Desa Sroyo Kecamatan .... Al-Umron: Jurnal ..., 1(1), 15-21. http://ejournal.sunangiri.ac.id/index.php/AL-UMRON/article/view/255

Shimp, T. A. (2003). Periklanan, Promosi dan Aspek Tambahan Komunikasi Pemasaran terpadu (5th ed.). Erlangga.

Siswati, E., \& Alfiansyah, R. (2020). Keunggulan Bersaing Umkm Kuliner Berbasis Inovasi (Studi Pada Umkm Keripik Samiler Kasper Di Sidoarjo). IDEI: Jurnal Ekonomi \& Bisnis, 1(2), 84-90. https://doi.org/10.38076/ideijeb.v1i2.18

Siti Komariah. (2020). Analisis Strategi Pengembangan Usaha Gerabah Dalam Meningkatkan Kesejahteraan Pengrajin Dalam Pespektif Ekonomi Islam (Studi Usaha Gerabah di Pekon Podomoro Kecamatan Pringsewu Kabupaten Pringsewu). 1-77.

Sumidingrat Gunawan. (2002). Pemberdayaan Masyrakat dan Jaringan Pengaman Sosial. Gramedia.

Suryana. (2006). Kewirausahaan Pedoman Praktis Kiat dan Proses Menuju Sukses (1st ed.). Salemba Empat. 
Tjiptono, F. (2005). Pemasaran Jasa (1st ed.). Bayu Media Publishing.

W. M. Pride dan Ferrell, O. C. (1989). Pemasaran dan Praktek Sehari- hari (D. Wirajaya (ed.); VII). Binarupa aksara.

Wahyunti, S. (2020). Peran Strategis UMKM Dalam Menopang Perekonomian Indonesia Di Tengah Pandemi Covid 19. Jurnal Ekonomi Syariah, 3(2), 280302. 